\title{
An Analysis of the Business Enterprise Research and Development Expenditures Composition in Brazil*
}

\author{
Luiz Ricardo Cavalcante**
}

\begin{abstract}
In this paper, business enterprise $R \& D$ expenditures in Brazil are decomposed to stress the role of the individual firms' innovation efforts and of the industrial structure in the aggregate levels of this indicator. Based on the aggregation of the manufacturing industry sectors into four groups according to their technological intensity, the ratio between R\&D expenditures and net sales of the manufacturing in Brazil was analyzed and compared with the ratios observed in Germany, in the United States and in Canada. It is argued that if the target of Brazilian innovation policy is to increase the ratio between business enterprise $R \& D$ expenditures and the GDP, the focus should be placed on high and medium-high technology sectors. On the other hand, additional instruments targeting medium-low and low technology sectors should be used to allow them to benefit from incremental innovations and from the absorption of practices not directly related to R\&D.
\end{abstract}

\footnotetext{
* Parts of this paper have been previously published in Portuguese by Cavalcante and De Negri (2010) and by Araújo and Cavalcante (2011) in a bulletin used to report preliminary results achieved in researches in the Brazilian Institute for Applied Economic Research (Ipea). The author would like to thank Bruno César Araújo and Fernanda De Negri for the discussions during the coauthoring of those short papers. Thanks also to Giovanni Dosi, who discussed a preliminary version of this paper during Globelics 2012 in Hangzhou, China, and to two RBI anonymous referees for their comments and suggestions.

** Consultor legislativo do Senado Federal, Brasília (DF), Brasil. E-mail: luiz.ricardo.teixeira.cavalcante@gmail.com
} 
KEYWORDS | Innovation Policies; Structural Change; R\&D Expenditures; Business Enterprise R\&D Expenditures; Technological Intensity

JEL-CODE | O3

\section{Uma Análise da Composição dos Gastos Empresariais em Pesquisa e Desenvolvimento no Brasil}

\section{RESUMO}

Neste trabalho, os gastos empresariais em P\&D no Brasil são decompostos para explicitar o papel dos esforços de inovação das firmas individuais e da estrutura produtiva nos níveis agregados desse indicador. Com base na agregação dos setores da indústria de transformação em quatro grupos de acordo com seus níveis de intensidade tecnológica, analisa-se a relação entre gastos em P\&D e receita operacional líquida no Brasil, comparando-a com os indicadores referentes à Alemanha, aos Estados Unidos e ao Canadá. Argumenta-se que, se o objetivo das políticas de inovação no Brasil é aumentar a relação entre gastos empresariais em P\&D e PIB, seu foco deveria recair sobre os setores de alta e média-alta tecnologia. Por outro lado, instrumentos adicionais de política com foco nos setores de média-baixa e baixa tecnologia devem ser adotados para que esses segmentos beneficiem-se de inovações incrementais e da absorção de novas práticas não diretamente associadas às atividades de P\&D.

Palavras-Chave | Políticas de Inovação; Mudança Estrutural; Gastos em P\&D; Gastos Empresariais em P\&D; Intensidade Tecnológica

CÓdigo JEL | O3 


\section{Introduction}

The growing acknowledgement of the association between science, technology and innovation (ST\&I) and economic and social development has led many countries to establish goals aiming at increasing their efforts of research and development (R\&D) as a percentage of their gross domestic product (GDP). This indicator measures the degree of R\&D intensity within a country and is commonly used as a summary statistic for international comparisons. In the European Union, for example, most countries established targets for their R\&D expenditures as a percentage of GDP as a consequence of the "Lisbon Agenda". Even considering that many countries have fallen short of the $3.0 \%$ target, innovation policies have been widely adopted in most of them (EUROPEAN COMMISSION, 2011). On several occasions, the focus of the policies relies on the business enterprise R\&D expenditures / GDP as it tends to capture the involvement of firms in innovation activities. Particularly in Brazil, one of the targets of the industrial policy issued in 2011 is to increase business enterprise R\&D expenditures / GDP from an estimated value of $0.59 \%$ in 2010 to $0.90 \%$ in $2014 .^{1}$ That is an ambitious goal especially if the recent pace of this indicator is taken into account.

National R\&D intensity indicators (such as business enterprise R\&D expenditures / GDP or business enterprise R\&D expenditures / net sales, for example), however, result from firms' or sectors' R\&D intensity weighted by their relative share in the industrial structure. It means that the national average can increase by increasing firms' or sectors' R\&D intensity or the relative share of more R\&D intensive firms in the industrial structure. This apparently straightforward proposition is frequently neglected, as most policies which target the ratio business enterprise R\&D expenditures / GDP focus essentially on fiscal and financial incentives and on the strengthening of the links between firms and universities aiming at increase firms' or sectors' R\&D intensity. On the other hand, structural changes, though strictly related to the increasing of national R\&D intensity indicators, are not - at least in historical perspective - the focus of innovation policies adopted in countries like Brazil. ${ }^{2}$

1 In this paper, the expression "business enterprise R\&D expenditures" is used instead of "private R\&D expenditures" because, on several occasions, this indicator includes expenditures by state firms (such as Petrobras in the Brazilian case). The expression "business enterprise R\&D expenditures" is used by the OECD Directorate for Science, Technology and Industry.

2 In spite of that, some innovation policies recently adopted in Brazil claim to focus on high and medium-high technology sectors This is the case, for example, of the so called "Inova Empresa" plan launched by the federal government in 2013. 
The aim of this paper is discuss the ways to increase business enterprise $R \& D$ expenditures in Brazil based on a sectoral decomposition of this indicator. The sectors that comprise the manufacturing industry are aggregated into four groups according to their technological intensity (high, medium-high, medium-low and low technology) and the contribution of each group to the national average is calculated in order to stress the role not only of firms R\&D intensity but also of the industrial structure in the determination of the overall R\&D intensity of the Brazilian economy. A set of selected countries is used as counterfactual and to support simulations of the behavior of the national indicators. The paper is structured in four additional sections besides this introduction. In section 2, the use of business enterprise $R \& D$ expenditures as a target for innovation and industrial policies is discussed. The reliance of this indicator on the industrial structure is also discussed in this section. The third section focuses the methodological procedures used in this paper. In particular, the model of analysis, the procedures to aggregate sectors according to their technological intensity and the source of data are presented. In section 4, the main results of the analysis are discussed. Based on the aggregation of the 32 sectors that comprise the manufacturing industry into four groups according to their technological intensity, the reasons that explain Brazil's relatively low performance as regards the ratio between expenditures on R\&D and net sales are analyzed and alternative ways to increase business enterprise $R \& D$ expenditures in Brazil are discussed. Finally, the main conclusions of the paper are summarized in section 5 .

\section{Theoretical background}

\subsection{The business enterprise R\&D expenditures indicator}

The main source of the business enterprise $R \& D$ expenditures in Brazil is the Brazilian Innovation Survey (PINTEC), which follows, in general terms, the guidelines established by the Oslo Manual (OECD, 2005). This survey is periodically carried out by IBGE and has "the main objective of supplying information for the construction of indicators of technological innovation activities of Brazilian firms" (IBGE, 2010, p. 9). Essentially, the innovation surveys built in accordance with the model proposed by the Oslo Manual aim at obtaining output indicators and, therefore, advances in relation to the traditional input indicators, such as R\&D expenditures. 
Considering that the concept of innovation is very diffuse, the Oslo Manual, whose first edition was published in 1992, intended to harmonize the methodologies adopted in different countries. Moreover, the manual began to guide the collection and systematization of standardized information on i) the types of innovation obtained by the firm (product and process, for example); ii) the sources of technological knowledge; iii) the investments done (in R\&D and in other possible sources of innovation); iv) the objectives intended with these activities; $v$ ) the obstacles found; and vi) the impacts of innovation activities. This list of standardized information reveals that innovation surveys started not only to subsidize the analyses of the results of innovation processes, but also to supply relevant information about the input indicators themselves. Thus, in Brazil, for example, business enterprise R\&D expenditures are calculated by the Ministry of Science, Technology and Innovation (MCTI) based on data available in the PINTEC.

Innovation surveys have been systematically carried out since the 1990s in the countries that currently comprise the European Union and also in some other countries. In Brazil, in spite of the incipient initiatives of the National Association of Innovative Firms (ANPEI) back in the 1990s, innovation surveys started to be issued in 2000, when the first edition of the PINTEC was published. The results of these surveys have been used in many different ways, which go from characterizing the universe of innovative firms, going through international and sectoral comparisons and reaching, whenever micro-data are used, an analysis of the impacts caused by specific public policies. ${ }^{3}$

The dissemination of the use of innovation surveys, however, did not prevent some authors from highlighting some methodological limitations and the occasional inadequate use of the data available. Freeman and Soete (2007) mentioned that "like any other statistics, indicators on science, technology and innovation (STI) can be used and abused". Godin (n.d.), on the other hand, stresses the emphasis that ended up being given, in innovation surveys, to effort indicators and activities, and not to the output indicators, which constituted the original purpose of this

3 Regarding this last aspect, the vast bibliographic production - especially by authors linked to the Centre for European Economic Research $(Z E W)$ - has been trying to verify the impacts caused by public R\&D policies on firms, by using individualized firm data obtained in the many editions of the Community Innovation Survey of the European Union. In the same way, in Brazil, Avellar (2008) evaluated, using data from the PINTEC, the impacts of the Industrial Technological Development Program (PDTI) on firms. In the same way, De Negri, De Negri and Lemos (2008a) assessed the impacts of the National Technological Development Support Program (ADTEN) on R\&D expenditures, on patents and on the economic and financial performance of firms. In a similar effort, these same authors evaluate the impacts of the National Fund for Scientific and Technological Development (DE NEGRI; DE NEGRI; LEMOS, 2008b). Araújo et al. (2010), on the other hand, analyzed the impacts of the access to sectorial funds on the technological efforts and the results achieved by firms. 
type of research. One of the strongest critiques to innovation surveys was presented by Arundel (2006; 2007), who, in line with Godin (n.d.), says that, in Europe, public innovation policies are still greatly based on the well-established indicators of R\&D expenditures. This perception led him to propose the "Oslo paradox", according to which "we see innovation surveys everywhere, but where is the impact on innovation policies?"

Although collected in the surveys, output indicators, however, are not so widely used. This is the case, for example, of the percentage of innovative firms, a very intuitive output indicator that allows immediate international, inter-sectoral and inter-temporal comparisons. However, this indicator is limited by the methodological difficulties associated to the verification of the broad concept of innovation and due to its dependence on factors such as market structure. Besides, the dynamics of the market strongly affects this indicator. ${ }^{4}$ The methodological limitations of such output indicators explain why, when analyzing the path of innovation indicators, one also reports to the indicators related to technological efforts.

Thus, due to the methodological difficulties mentioned above, input indicators are many times considered to be more robust measures of innovation in the business enterprise sector than the innovation rates themselves. Although this perception may seem to contradict the very essence of the Oslo Manual, the fact is that R\&D expenditures as a percentage of GDP or net sales remain in the center of all debates about public ST\&I policies, both in the OECD countries and in countries like Brazil. In fact, surveys such as the PINTEC provide elements that subsidize the calculation of the ratio between business enterprise R\&D expenditures and GDP, which is used in international comparisons and constitutes, as mentioned in the introduction of this paper, the indicator used to set innovation and industrial policies targets. On the other hand, the ratio between $R \& D$ expenditures and value added (or net sales) is one of the most widely used indicators to assess the technological intensity of firms and economic sectors. ${ }^{5}$

4 The stylized situation below illustrates the limitations of the percentage of innovative firms and shows its relationship with the market structure. One can assume, for example, that in the country (or sector, according to each case) there are three firms: A (innovates); B (innovates); and C (does not innovate). In this case, the percentage of innovative firms is 67\%. However, if $\mathrm{A}$ and $B$ merge (aiming, for example, at increasing their R\&D scale), the country (or sector) would then be comprised by two firms: $\mathrm{AB}$ (innovates); and $\mathrm{C}$ (does not innovate). In this case, there would be a reduction of the percentage of innovative firms to $50 \%$.

5 The ratio between R\&D expenditures and value added is adopted by the OECD, for example. However, in the circumstances the value added is not available - as in the case of the Brazilian Innovation Survey - the ratio between R\&D expenditures and net sales may be used without bringing about major changes in the analysis. 


\subsection{Business enterprise R\&D expenditures and industrial structure}

Several authors reported a direct relationship between business enterprise R\&D expenditures indicators and industrial structure. Arruda, Velmulm and Holanda (2006, p. 57), for example, when segmenting the ratio between R\&D expenditures and net sales according to the different sectoral levels of technological intensity, argued that:

In the USA, most (60\%) spending on R\&D in the industry is carried out by the high technology segment. The same can be observed in Ireland, Canada and Finland. In the European Union and in Japan, spending on R\&D in the high technology industry represents, respectively, $48 \%$ and $46 \%$.

Still according to these authors:

In Germany, medium-high technology segments represent more than 50\% of the investments in $R \& D$. Norway is the only OECD country in which medium-low and low technology industries represent more than $40 \%$ of the investments in $R \& D$, of the industrial sector.

These analyses reinforce the perception that international comparisons of technological efforts must consider the performance of each sector in relation to other countries as well as how the industrial structure is established. On several occasions, factors endowments explain, at least in part, the difference between industrial structures among countries.

A particularly interesting approach on this issue has been proposed by Maloney and Rodríguez-Clare (2007) based upon the concept of "innovation shortfall". They argue that low R\&D investment rates are also associated to the economy's pattern of specialization and to impediments to accumulation more generally. Using the Chilean case as a reference, Maloney and Rodríguez-Clare (2007) calibrate a model to estimate R\&D gaps that should be expected given a country's investments in physical and human capital. In short, the central argument is that poor Latin-American R\&D indicators might be a natural consequence of a particular economic structure (CRESPI et al., 2011).

The perception that the national $R \& D$ intensity (as measured by business enterprise R\&D expenditures / GDP or business enterprise R\&D expenditures / net sales, for example) results from firms R\&D intensity weighted by the industrial 
structure (because some sectors are more R\&D intensive than others) led Araújo and Cavalcante (2011) to propose a systematization of the factors that contribute to the formation of the national R\&D intensity shown in Figure 1.

FIGURE 1

Factors that contribute to the formation of the national R\&D intensity

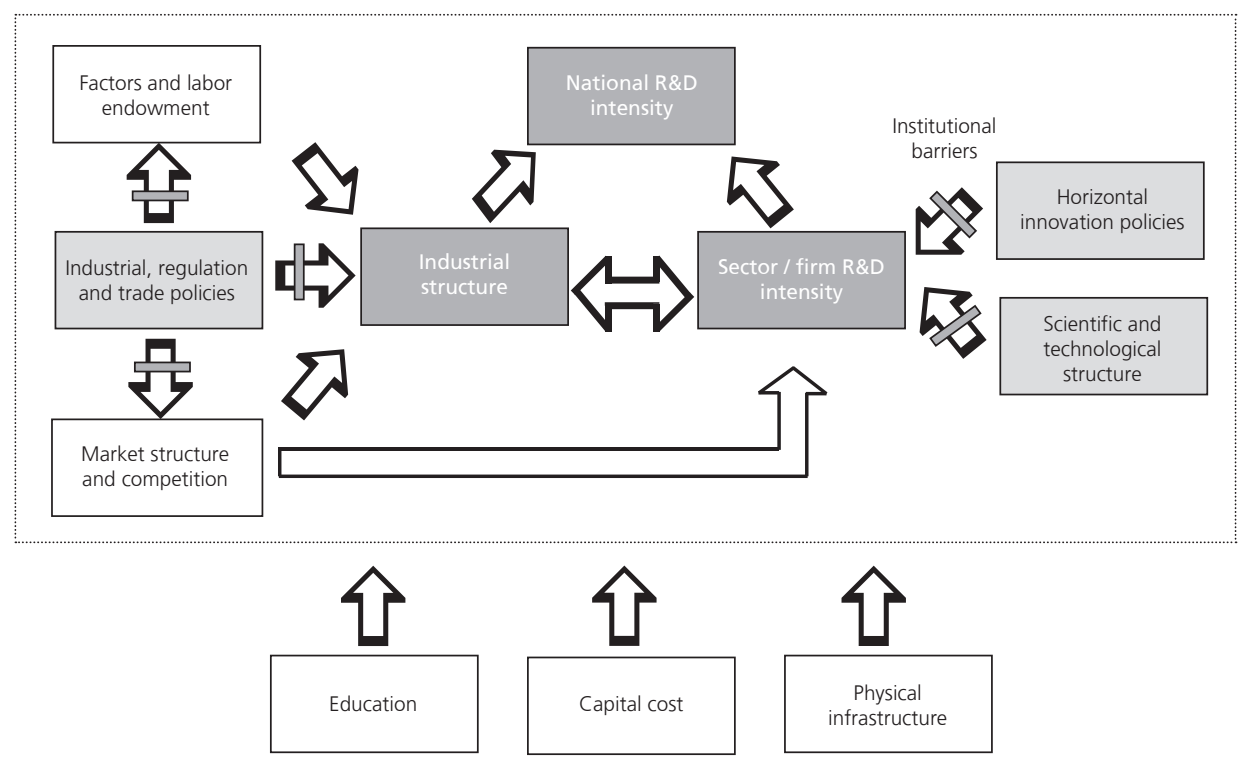

Source: Araújo and Cavalcante (2011).

In Figure 1, the basic relationship between the national $R \& D$ intensity, the industrial structure and the sector or firms $R \& D$ intensity is indicated in the darker gray boxes, while the factors that contribute to their formation is indicated in lighter gray or in white. The mutual relationship between the industrial structure and the sector or firms R\&D intensity explains the two-way arrow connecting these boxes. The light gray was used to highlight the factors on with policy makers might have direct control. These factors include i) industrial, regulation and trade policies; ii) horizontal innovation policies and iii) scientific and technological structure. In the white boxes the factors on which the government has little or no influence are indicated (factors and labor endowment and market structure and competition). The left part of the framework indicates the factors that affect the industrial structure, while in the right part of it the factors that affect firms or sectors $R \& D$ intensity are highlighted. On several occasions, however, the influence of a factor on the other is harmed by what they called "institutional barriers", which might result, for example, 
of transaction costs and uncertainties regarding government policies. Finally, a set of systemic factors such as education, capital cost and physical infrastructure influence in practice all the previously mentioned factors. That explains why the systemic factors influence the whole set indicated inside the dashed line box.

Concerning the Brazilian case, Furtado and Carvalho (2005) show that the local industry presents lower levels of technological efforts as compared to more developed countries. These differentials support a proposition of a sectoral classification of technological intensity slightly different from the one used by the Organization for Economic Cooperation and Development (OECD). Their main goal is to "identify the critical factors which explain the differences in sectoral patterns between Brazil and more developed countries" (FURTADO; CARVALHO, 2005, p. 83). Using the OECD classification, Zucoloto and Toneto Junior (2005) argue that, based on data from the 2003 PINTEC, the technological effort of the Brazilian industry is limited in relation to OECD countries and they attribute this result to the differences that can be observed in the sectors that are intensive in technology, even if a small part of it could be credited to the differences between the industrial structure in Brazil and in the other countries analyzed. These papers make it clear that analyses of the Brazilian case that explicit the different levels of technological intensity of the industry can contribute to a better understanding of the relatively low indicators of $R \& D$ expenditures / net sales and, as a consequence, of the reduced ratio between $\mathrm{R} \& D$ expenditures and the GDP observed in the country.

\section{Methodological procedures}

\subsection{Model of analysis}

The starting point of the model of analysis used in this paper is the definition of an aggregate indicator of business enterprise $R \& D$ expenditures in Brazil. As shown in the previous section, country level analyses of business enterprise $R \& D$ expenditures usually rely on the ratio between these expenditures and GDP. On the other hand, when the analysis focuses the technological intensity of firms and economic sectors, the ratio between R\&D expenditures and value added (or net sales) is more frequently used because the contribution of firms and sectors to GDP is not as easily obtained as their contribution to the total value added (or net sales). Although different, these indicators are clearly interrelated. In this paper, most analyses will be carried out using the ratio $R \& D$ expenditures / net sales because 
the data required to calculated these indicators are directly available both for Brazil and for some selected countries used as a reference in this paper.

The ratio $\mathrm{R} \& \mathrm{D}$ expenditures / net sales $\left(\frac{R D}{S A L E S}\right)$ or the average technological intensity $(T I)$ is given by the ratio between the sum of the R\&D expenditures and the sum of the net sales of the $N$ sectors (or aggregate of sectors) considered in the analysis as shown in equation 1 :

$$
T I=\frac{R D}{\text { SALES }}=\frac{\sum_{i=1}^{N} r d_{i}}{\sum_{i=1}^{N} \text { sales } i}=\frac{r d_{1}}{\sum_{i=1}^{N} \text { sales } i_{i=1} \text { sales } i}+\frac{r d_{2}}{\sum_{i=1}^{N} \text { sales }_{i}}
$$

In this equation, $R D$ corresponds to the total internal and external business enterprise R\&D expenditures, ${ }^{6}$ SALES corresponds to the total net sales and $r d_{i}$ e sales $_{i}$ to the R\&D expenditures and net sales of the sector (or aggregate of sectors) $i$. Equation 1 may be rewritten as one multiplies each $\frac{p d_{1}}{\sum_{i=1}^{N} \text { salesi }_{i}}$ by $\frac{\text { sales }_{i}}{\text { sales }_{i}}$ :

$T I=\frac{R D}{\text { SALES }}=\frac{r d_{1}}{\sum_{i=1}^{N} \text { sales }_{i}} \frac{\text { sales }_{1}}{\text { sales }_{1}}+\frac{r d_{2}}{\sum_{i=1}^{N} \text { salesi } i_{\text {sales }}}+\ldots+\frac{r d_{N}}{\sum_{i=1}^{N} \text { salesi }_{2}} \frac{\text { sales }_{N}}{\text { sales }_{N}}$

Rearranging,

$T I=\frac{R D}{\text { SALES }}=\frac{\text { sales }_{1}}{\sum_{i=1}^{N} \text { sales }_{i}} \frac{r d_{1}}{\text { sales }_{1}}+\frac{\text { sales }_{2}}{\sum_{i=1}^{N} \text { salesi }_{i}} \frac{r d_{2}}{\text { sales }_{2}}+\ldots+\frac{\text { sales }_{N}}{\sum_{i=1}^{N} \text { salesi }_{i}} \frac{r d_{N}}{\text { sales }_{N}}$

In other words, the average technological intensity is given by the sum of the product of the relative share of the sector or aggregate of sectors $i$ in the total net sales $w i=\left(\frac{\text { sales }_{1}}{\sum_{i=1}^{N} \text { sales }_{i}}\right)$ and the technological intensity of the sector or aggregate of sectors $i\left(t i_{i}=\frac{r d_{i}}{\text { sales }_{1}}\right)$ :

$T I=\frac{R D}{S A L E S}=w_{1} t i_{1}+w_{2} t i_{2}+\ldots+w_{N} t i_{N}=\quad w_{i} t i_{i}$

6 In this paper, both internal ("intramural") and external ("extramural") R\&D expenditures are used. The option for using the external R\&D expenditures along with the internal $R \& D$ expenditures relies on the fact that in Brazil the ratio business enterprise R\&D expenditures / GDP is estimated on the basis of both internal and external \&\&D expenditures. See note 3 for the national R\&D expenditures issued by the MCTI. Available at: <http://www.mct.gov.br/index.php/content/view/29144/ Dispendio_nacional_em_pesquisa_e_desenvolvimento_P_D_em_valores_correntes_em_relacao_ao_total_de_P_D_e_ao_produto_interno_bruto_PIB_por_setor_institucional.html>. Access on: Nov. 20th 2013. 
In equation 4 , each term $w_{i} t i_{i}$ corresponds to the contribution of the sector or aggregate of sectors to the national average technological intensity. ${ }^{7}$

This simple algebraic exercise reveals that the indicators used to establish the targets of the national innovation policies are weighted averages. This perception - which is behind the analyses mentioned in subsection 2.2 of this paper - is the starting point of a model which takes into account the fact that some sectors, by their very intrinsic characteristics, invest more in $R \& D$ than more traditional ones.

\subsection{Aggregation according to the technological intensity}

As mentioned in section 2 of this paper, a particularly interesting way to analyze the average technological intensity is to aggregate the 32 sectors that comprise the manufacturing industry into four groups according to their technological intensity (high, medium-high, medium-low and low technological intensity). For this purpose, the sectoral classification of technological intensity of the Organization for Economic Cooperation and Development (OECD) was used. ${ }^{8}$

The OECD classification has been used both by the Brazilian Institute of Geography and Statistics (IBGE) based on the Brazilian Standard Industrial Classification (CNAE 2.0) and by the Statistical Office of the European Union (Eurostat) based on the European Classification of Economic Activities (NACE Rev. 2). These aggregations are available at 3-digit level sectoral classification in both cases. However, in some occasions, restrictions of the data sources used restrict the aggregations only on a 2-digit level. Concerning the manufacturing industry - which is the focus of this paper - this classification is indicated in box 1 below. As the OECD uses the United Nations' International Standard Industrial Classification (ISIC), which corresponds to a more general version of NACE, in box 1 this classification is included as well. As shown in box 1, at 2-digit level, the aggregations of the manufacturing industry according to the technological intensity are identical for CNAE 2.0, NACE Rev. 2 and ISIC.

7 It is noteworthy that $T I=\frac{R D}{S A L E S}$ is, by its own definition, less sensitive to $w_{i}$ than to $t i_{i}$ because the partial derivative of normalized variables is affected by the fact that $\sum_{i=1}^{N} w_{i}=1$. In the case of just two sectors, for example, $T I=\frac{R D}{S A L E S} w_{1} t i_{1}+$ $w_{2} t i_{2}$. The partial derivative of $T I$ in regards to $w_{1}$ is given by $\frac{\partial \frac{R D}{S A L S}}{\partial w_{1}}=t i_{1}-t i_{2}$. The presence of $-t i_{2}$ is a consequence of the fact that $w_{1}+w_{2}=1$. On the other hand, partial derivative of $T$ in regards to $t i_{1}$ is simply $\frac{\partial}{\frac{S A L E S}{a_{t}}}=w_{1}$

8 Further analyses may considered, along with the of the sectoral classification of technological intensity of the OECD, Pavitt's (1984) taxonomy, which consists of four categories of industrial firms: i) supplier-dominated; ii) scale-intensive; iii) specialized suppliers; and iv) science-based. 


\section{BOX 1}

Aggregations of the manufacturing industry according to the technological intensity based on the Brazilian Standard Industrial Classification (CNAE 2.0), the European Classification of Economic Activities (NACE Rev. 2) and the International Standard Industrial Classification (ISIC)

\begin{tabular}{|l|l|}
\hline \multicolumn{1}{|c|}{$\begin{array}{c}\text { Technological } \\
\text { intensity }\end{array}$} & \multicolumn{1}{c|}{ CNAE, NACE ISIC (2-digit level) } \\
\hline High & $\begin{array}{l}21 \text { Manufacture of basic pharmaceutical products and pharmaceutical } \\
\text { preparations. } \\
26 \text { Manufacture of computer, electronic and optical products. }\end{array}$ \\
\hline Medium-high & $\begin{array}{l}20 \text { Manufacture of chemicals and chemical products. } \\
27 \text { to } 30 \text { Manufacture of electrical equipment, Manufacture of machinery and } \\
\text { equipment n.e.c., Manufacture of motor vehicles, trailers and semi-trailers, } \\
\text { Manufacture of other transport equipment. }\end{array}$ \\
\hline Medium-low & $\begin{array}{l}19 \text { Manufacture of coke and refined petroleum products. } \\
22 \text { to 25 Manufacture of rubber and plastic products, Manufacture of other } \\
\text { non-metallic mineral products, Manufacture of basic metals, Manufacture of } \\
\text { fabricated metal products, except machinery and equipment. } \\
33 \text { Repair and installation of machinery and equipment. }\end{array}$ \\
\hline Low & $\begin{array}{l}10 \text { to } 18 \text { Manufacture of food products, beverages, tobacco products, textiles, } \\
\text { wearing apparel, leather and related products, wood and of products of wood, } \\
\text { paper and paper products, printing and reproduction of recorded media. } \\
31 \text { to 32 Manufacture of furniture, Other manufacturing. }\end{array}$ \\
\hline
\end{tabular}

Source: Eurostat (http://epp.eurostat.ec.europa.eu/cache/ITY_SDDS/Annexes/htec_esms_an3.pdf) and IBGE (Diretoria de Pesquisas, Coordenação de Indústria). The correspondence between NACE and ISIC was established based upon: <http://circa.europa.eu/irc/dsis/nacecpacon/info/data/en/NACE\%20Rev\%202\%20structure\%20and\%20 correspondences\%20NACE\%20Rev\%201\%201\%20and\%20ISIC\%20Rev\%204.pdf>. Access on: Jun. $06^{\text {th }} 2012$. Elaborated by the author.

As it can be seen in Box 1, sectors like other transportation equipment would have to be disaggregated, because its subsectors belong to different categories of technological intensity. The manufacturing of aircrafts is classified as high intensity, while the manufacturing of trains and the naval sector are medium-high, and the manufacturing of bicycles, medium-low. Since it was not possible to disaggregate the sector for this paper, it was classified, in the 2-digit aggregation level, as medium-high technological intensity. This procedure tends to reduce the relative share of high technology sectors and to increase the share of medium-high technology. 


\subsection{Source of data}

The data used in this paper were obtained directly from the innovation surveys or from tabulations of these surveys available at the OECD site. For the Brazilian case, IBGE performs, usually every three years, the Brazilian Innovation Survey (PINTEC), whose edition related to the period between 2006 and 2008 was published in 2010. In spite of the availability of more frequent alternative indicators, PINTEC is the most complete and important representation of innovation in the Brazilian economy.

International comparisons of $R \& D$ expenditures data, however, shall be made carefully, as not always $R \& D$ expenditures data are collected the same way. As a result, comparisons between Brazil and European Union countries tend to be more appropriate than comparisons between Brazil and the United States, for example, because the European Commission's Community Innovation Survey (CIS) and IBGE's Brazilian Innovation Survey (PINTEC) follow similar data collecting procedures, whereas the North-American Business R\&D and Innovation Survey (BRDIS) adopts specific patterns suitable for the case of the United States. Besides, the net sales or the aggregate value used to calculate the R\&D intensity shall refer to the same sample of firms. However, on several occasions, R\&D expenditures are obtained from innovation surveys, while aggregate values come from the national accounts. Although not always these limitations can be easily overcome, international comparisons are useful to explain how the different industrial structures and different levels of R\&D expenditures across sectors explain the different levels of average technological intensity across countries.

\section{Results}

According to the data available in the last PINTEC, in aggregated terms, total expenditures on innovative activities in Brazil reached, in 2008, $\mathrm{R} \$ 54.1$ billion. From this total amount, $\mathrm{R} \$ 15.2$ billion refer to expenditures on internal $\mathrm{R} \& \mathrm{D}$ activities and $\mathrm{R} \$ 2.4$ billion to the external acquisition of R\&D. These are essentially the data used by the MCTI to calculate the ratio between business enterprise R\&D expenditures and GDP for the country. The figures released by the MCTI are obtained from the PINTEC, but need to be treated, since, for example, it is necessary to subtract from the total amount the values invested by R\&D institutes, which have already been included in the surveys of public investments such as the 
Brazilian Agricultural Research Corporation (Embrapa) and the Oswaldo Cruz Foundation (Fiocruz). After these procedures, the MCTI concluded that business enterprise R\&D expenditures in Brazil reached, in 2008, the equivalent to $0.53 \%$ of the GDP, against $0.49 \%$ in 2005 . The increase of the ratio R\&D / GDP reflects, obviously, the more accelerated expansion of the R\&D expenditures than of the GDP in the period between 2005 and 2008, and indicates a meaningful expansion of the technological efforts of the Brazilian economy at a moment that is marked by higher growth rates. ${ }^{9}$

The growth observed in Brazil, which corresponds to 0.04 percentage points does not seem to have been significantly superior to the rest of the world in the period immediately before the world economic crisis. ${ }^{10}$ In fact, according to data available at the Eurostat site, ${ }^{11}$ the growth of the ratio between business enterprise R\&D expenditures and GDP in countries such as Portugal, Finland and Denmark was superior to 0.20 percentage points between 2005 and 2008. Even if these variations are credited to isolated or idiosyncratic initiatives, because the GDP of these countries (in absolute terms) is relatively small, the performance of the United States - that presented an even higher variation - shows that this explanation alone would not be satisfactory. In China, this ratio went from $0.90 \%$ to $1.08 \%$ in the period analyzed. The significant increase of the average ratio between R\&D and GPD in China suggest that changes in the industrial structure may play an important role in the growth of a country's technological efforts.

A way of exploring the reasons behind Brazil's relatively low performance as regards the ratio between R\&D expenditures and GDP is to look at the evolution of the ratio between R\&D expenditures and net sales of the 32 sectors that comprise the manufacturing industry aggregated into the four groups according to their technological intensity described in section 3. This kind of analysis allows also a look on the alternative ways that can be used to increase this ratio in the country.

9 Interestingly, in 2009, the ratio business enterprise R\&D expenditures / GDP reached $0.56 \%$ ( 0.03 percentage points above the value in 2008). This apparently fast growth when the world economic crisis reached Brazil, however, is explained by a limitation of the indicator: while business enterprise R\&D expenditures in 2009 are extrapolated from the trend between 2005 and 2008 , the GPD used to calculate the ratio is the one effectively observed. As the GDP growth in 2009 was $-0.33 \%$, the ratio grew faster than expected. According, in 2010, when GPD growth was $7.53 \%$, the ratio fell to $0.55 \%$. The high rate of growth of the GPD in 2010 explains why preliminary estimates of the ratio business enterprise R\&D expenditures / GDP were set at $0.59 \%$.

10 As business enterprise $R \& D$ expenditures tend to be procyclical, the growth rate of these ratios are expected to lower in the period after the world economic crisis period.

$11<$ http://epp.eurostat.ec.europa.eu/portal/page/portal/eurostat/home/>. 
According to data obtained from the PINTEC (IBGE, 2007; 2010), the average ratios between R\&D expenditures and net sales in 2005 and 2008 were $0.66 \%$ and $0.75 \%$ respectively. The data related to each one of the four groups that comprise the manufacturing industry for both years are shown in Tables 1 and 2 .

TABLE 1

Expenditures in internal and external R\&D activities and net sales according to technological intensity, manufacturing industry

Brazil - 2005

\begin{tabular}{l|c|c|c|c|c}
\hline & Technological \\
intensity & $\begin{array}{c}\text { Number } \\
\text { of firms }\end{array}$ & $\begin{array}{c}\text { Net } \\
\text { sales } \\
(\mathbf{R} \text { thousands) }\end{array}$ & $\begin{array}{c}\text { Spending } \\
\text { on internal and } \\
\text { external R\&D } \\
\text { activities } \\
\text { (R\$ thousands) }\end{array}$ & $\begin{array}{c}\text { Spending on } \\
\text { internal and } \\
\text { external } \\
\text { R\&D } \\
\text { activities / net } \\
\text { sales } \mathbf{\%})\end{array}$ & $\begin{array}{c}\text { Contribution to } \\
\text { the average of the } \\
\text { manufacturing } \\
\text { industry } \\
\text { (equation 4) } \\
(\%)\end{array}$ \\
\hline High & 1,130 & $80,358,882$ & $1,278,904$ & 1.59 & 0.11 \\
Medium-high & 4,297 & $390,623,848$ & $4,259,444$ & 1.09 & 0.35 \\
Medium-low & 4,794 & $338,550,865$ & $1,709,059$ & 0.50 & 0.14 \\
Low & 9,400 & $393,165,386$ & 732,016 & 0.19 & 0.06 \\
Total & $\mathbf{1 9 , 6 2 1}$ & $\mathbf{1 , 2 0 2 , 6 9 8 , 9 8 1}$ & $\mathbf{7 , 9 7 9 , 4 2 3}$ & $\mathbf{0 . 6 6}$ & $\mathbf{0 . 6 6}$ \\
\hline
\end{tabular}

Source: IBGE (2007). Elaborated by the author.

TABLE 2

Expenditures in internal and external R\&D activities and net sales according to technological intensity, manufacturing industry

Brazil - 2008

\begin{tabular}{l|c|c|c|c|c}
\hline $\begin{array}{l}\text { Technological } \\
\text { intensity }\end{array}$ & $\begin{array}{c}\text { Number of } \\
\text { firms }\end{array}$ & $\begin{array}{c}\text { Net sales } \\
(\mathbf{R} \mathbf{S} \text { thousands) }\end{array}$ & $\begin{array}{c}\text { Spending on } \\
\text { internal and } \\
\text { external R\&D } \\
\text { activities } \\
\text { (R thousands) }\end{array}$ & $\begin{array}{c}\text { Spending } \\
\text { on internal } \\
\text { and external } \\
\mathbf{R} \& D \\
\text { activities } \\
/ \text { net sales } \\
(\%)\end{array}$ & $\begin{array}{c}\text { Contribution to } \\
\text { the average of the } \\
\text { manufacturing } \\
\text { industry }\end{array}$ \\
(equation 4) (\%)
\end{tabular}

Source: IBGE (2010). Elaborated by the author. 
As shown in the tables above, medium-high technology sectors are those that most contribute to the total amount of internal and external R\&D expenditures in the manufacturing industry in Brazil $(0.35 \%$ in $0.66 \%$ and $0.37 \%$ in $0.75 \%$ in 2005 and 2008, respectively). ${ }^{12}$ The contribution of high and medium-high technology sectors together reaches $0.46 \%$ in $0.66 \%$ in 2005 and $0.47 \%$ in $0.75 \%$ in 2008 , although these sectors represent less than $40 \%$ of the total net sales. In other words, these sectors represent around $60 \%$ to $70 \%$ of the average $\mathrm{R} \& \mathrm{D}$ expenditures / net sales of the Brazilian manufacturing industry. However, high and medium-high technology sectors represent a much smaller share of the number of firms. In fact, in 2008, these firms represented less than $15 \%$ of the total sample. Low technological intensity sectors, on the other hand, even though representing a little less than one third of the net sales of the whole set, contribute with only 0.06 and 0.08 percentage points to the average of the manufacturing industry. This apparently straightforward conclusions pose a though decision to the policy makers, as a more efficient decision to increase Brazilian average ratio would be to place the focus on a smaller number of high and medium-high technology firms. However, on the other hand, innovation policies - especially in countries like Brazil - cannot neglect medium-low and low technology firms, which usually benefit from incremental innovations and from the absorption of practices not directly related to R\&D activities (see, for example, CASSIOLATO; LASTRES, 1999).

Some simulations using the data found in Table 2 are useful to explicit alternative public policies that can increase the average ratio between $R \& D$ expenditures and net sales in the Brazilian industry. For instance, an effort to double the ratio $\mathrm{R} \& \mathrm{D} /$ net sales of low technological intensity sectors (maintaining the other variables constant) would increase the average ratio $\mathrm{R} \& \mathrm{D} /$ net sales from $0.75 \%$ to $0.82 \%$. The same result could be achieved by acting upon medium-high technology firms; in this case, however, the required increase of the ratio R\&D / net sales would only be $21.15 \%$, in that group.

Another exercise that can be done using the data indicated in Table 2 is their comparison with similar data in more developed countries. That allows the breaking up of the reasons behind the low ratio R\&D expenditures / net sales observed in Brazil. The first comparison used Germany as a reference (Table 3). The choice of

12 The contribution of each group to the average of the manufacturing industry is calculated according to equation 4 indicated in section 3.1 . 
Germany as a reference is based on: $i)$ the data available in the CIS are methodologically comparable to the Brazilian data; and ii) the data are available for all sectors of the manufacturing industry indicated in the European Statistical Classification of Economic Activities (NACE). ${ }^{13}$

TABLE 3

Expenditures in internal and external R\&D activities and net sales according to technological intensity, manufacturing industry

Germany - 2008

\begin{tabular}{l|c|c|c|c|c}
\hline Technological & $\begin{array}{c}\text { Number } \\
\text { of firms }\end{array}$ & $\begin{array}{c}\text { Net sales } \\
(€ \text { thousands) }\end{array}$ & $\begin{array}{c}\text { Spending on } \\
\text { internal and } \\
\text { external R\&D } \\
\text { activities } \\
(€ \text { thousands) }\end{array}$ & $\begin{array}{c}\text { Spending } \\
\text { on internal } \\
\text { and external } \\
\text { R\&D } \\
\text { activities / } \\
\text { net sales (\%) }\end{array}$ & $\begin{array}{c}\text { Contribution to } \\
\text { the average of the } \\
\text { manufacturing } \\
\text { industry } \\
\text { (equation 4) (\%) }\end{array}$ \\
\hline High & 3,302 & $148,153,000$ & $10,152,650$ & 6.85 & 0.51 \\
Medium-high & 14,449 & $941,231,000$ & $36,684,480$ & 3.90 & 1.84 \\
Medium-low & 22,910 & $560,360,000$ & $3,296,340$ & 0.59 & 0.17 \\
Low & 22,991 & $339,514,000$ & $1,840,470$ & 0.54 & 0.09 \\
Total & $\mathbf{6 3 , 6 5 2}$ & $\mathbf{1 , 9 8 9 , 2 5 8 , 0 0 0}$ & $\mathbf{5 1 , 9 7 3 , 9 4 0}$ & $\mathbf{2 . 6 1}$ & $\mathbf{2 . 6 1}$ \\
\hline
\end{tabular}

Source: Community Innovation Survey (CIS) and OECD. Data available at: <http://epp.eurostat.ec.europa.eu/portal/page/portal/ eurostat/home/>. Elaborated by the author.

As Tables 2 and 3 are compared, it becomes clear that the manufacturing industry in Brazil still has a low ratio between $R \& D$ expenditures and net sales. If fact, while the Brazilian average is $0.75 \%$, in Germany the ratio reaches $2.61 \%$. The gap may be credited to two main factors:

Lower technological efforts by the firms in Brazil when compared to the firms in Germany. While high technology firms in Germany spent, on average, 6.85\% of their net sales in R\&D, in Brazil this percentage was only $1.89 \%$. Accordingly, medium-high and low technology firms in Brazil invested less in R\&D (as a percentage of their net sales) than firms in Germany. Only medium-low technological intensity firms invested, in Brazil, proportionally more than in Germany. ${ }^{14}$ Gaps for high and medium-high technology firms are especially noteworthy, and percentages in Germany correspond to 3.62 and 3.44 times the values observed in Brazil.

13 Conversely, for some other countries included in the CIS, disaggregated data are not available due to confidentiality reasons.

14 This apparent paradox might be a consequence of the inclusion of Petrobras (and its massive investments in research for offshore oil extraction) in medium-low technological intensity firms in Brazil. 
A lower share of more technologically intensive sectors in the Brazilian economic structure. While in Germany, high and medium-high technology sectors represented around $55 \%$ of the total net sales of the firms in the manufacturing industry, in Brazil this percentage was only $38 \%$. These data are essentially convergent with the data reported by Arruda, Velmulm and Holanda (2006, p. 57) and mentioned in section 2 of this paper.

Two hypothetical scenarios for the Brazilian ratio R\&D expenditures / net sales can be built upon the data regarding Germany. The first scenario considers the groups' R\&D intensities observed in Germany and apply them to the industrial structure observed in Brazil. As a result, the average would go from $0.75 \%$ to $2.00 \%$, which represents the upper limit of the ratio $\mathrm{R} \& \mathrm{D} /$ net sales in Brazil if no change is observed in the local industrial structure. The second scenario just keeps the groups' R\&D intensities observed in Brazil but assumes the same share observed in Germany for each group. This scenario leads to a R\&D / net sales ratio of $0.90 \%$. Although these scenarios may suggest a higher impact of groups' R\&D intensities as compared to industrial structure, it is noteworthy - as mentioned in section 3 - that ratio R\&D expenditures / net sales is, by its own definition, less sensitive to $w_{i}$ than to $t i_{i}$ because while $w_{i}$ is a normalized variable (i.e., $\sum_{i=1}^{N} w_{i}=1$, $t i_{i}$ is not limited by the values assumed by $t i_{j \neq i}$.

This kind of analysis can be easily extended to the other countries included in the CIS. Graph 1, in particular, plots the share of the high and medium-high technology sectors in the industrial structure and the national R\&D intensity average for these countries and Brazil.

Although Graph 1 shall be used cautiously, as disaggregated NACE data at 2-digit are not available for some countries, ${ }^{15}$ several insights can be extracted from it. Firstly, there is a "cloud" of more developed countries in the upper part of the graph. In these countries, the share of the high and medium-high technology sectors in the industrial structure is between $40 \%$ and $60 \%$ and the national R\&D intensity average varies from a little less than $1.50 \%$ to a little more than $2.50 \%$. The "cloud" in the lower part of the graph, on the other hand, is formed by countries whose national R\&D intensity average is below $1.00 \%$, although the share of the high and medium-high technology sectors may reach, in some cases, $60 \%$.

15 This is a consequence of the fact that the low number of firms of a given sector in a given countries would harm confidentiality of the CIS. In the case of Denmark, Finland, Luxembourg and United Kingdom it was not possible to re-aggregate sectors and these countries were excluded from the graph. 


\section{GRAPH 1}

Share of the high and medium-high technology sectors in the industrial structure and the national $R \& D$ intensity average, manufacturing industry

Selected countries - 2008

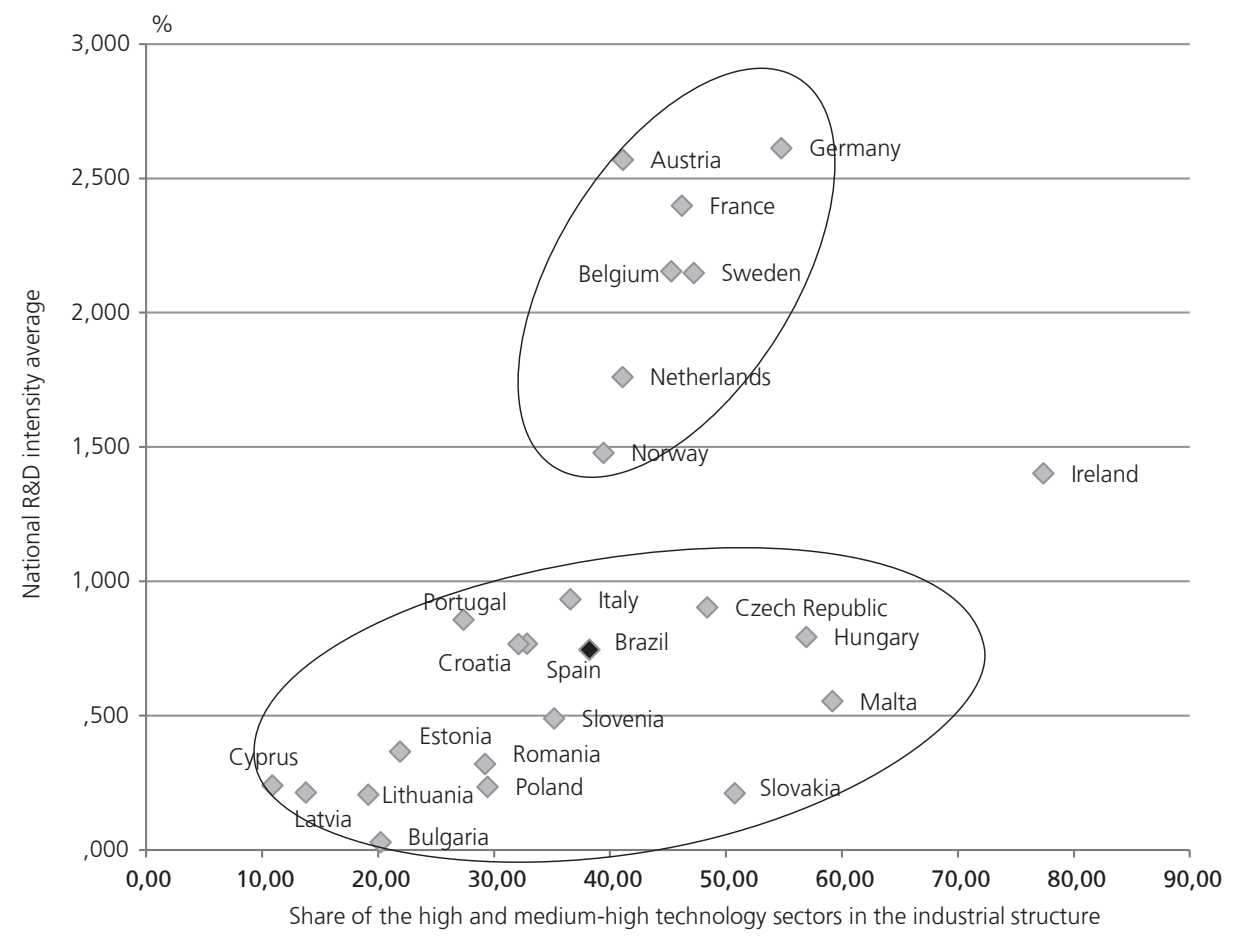

Source: IBGE (2010) and European Commission apud Araújo and Cavalcante (2011).

Although consistent from a methodological point of view, the comparison between Brazil and the European countries is limited because these countries have factors endowments that explain, at least in part, the difference between their industrial structures. In fact, as Germany, for example, is a relatively small country and the relatively smaller focus on medium-low and low technology sectors (such as the manufacture of coke and refined petroleum products or the manufacture of food products, beverages, tobacco products, textiles, wearing apparel, leather and related products, for example) might be considered a consequence of the absence of raw materials or cheap labor.

A comparison between Brazil and the United States or between Brazil and Canada, on the other hand, might provide an alternative view of the reasons behind the low ratios R\&D / net sales in the country. In fact, both the United States and 
Canada are endowed with natural resources and, in spite of having relevant high and medium-high technology sectors, these countries are important players in commodities production. However, as mentioned in subsection 3.3, data for the United States available in the Business R\&D and Innovation Survey (BRDIS) are not directly comparable to the Brazilian data. Besides, data for Canada - obtained from the OECD site - are not directly comparable to the Brazilian data either. In spite of these caveats, Tables 4 and 5 show the results for these countries.

TABLE 4

Expenditures in internal and external R\&D activities and net sales according to technological intensity, manufacturing industry

United States - 2008

\begin{tabular}{l|c|c|c|c|c}
\hline $\begin{array}{l}\text { Technological } \\
\text { intensity }\end{array}$ & $\begin{array}{l}\text { Number } \\
\text { of firms }\end{array}$ & $\begin{array}{c}\text { Net sales } \\
\text { (U\$\$ millions) }\end{array}$ & $\begin{array}{c}\text { Spending on } \\
\text { internal and } \\
\text { external R\&D } \\
\text { activities (U\$\$ } \\
\text { millions) }\end{array}$ & $\begin{array}{c}\text { Spending on } \\
\text { internal and } \\
\text { external R\&D } \\
\text { activities / net } \\
\text { sales (\%) }\end{array}$ & $\begin{array}{c}\text { Contribution to } \\
\text { the average of the } \\
\text { manufacturing } \\
\text { industry } \\
\text { (equation 4) (\%) }\end{array}$ \\
\hline High & n.a. & 963,033 & 116,549 & 12.10 & 2.64 \\
Medium-high & n.a. & $1,556,730$ & 46,440 & 2.98 & 1.05 \\
Medium-low & n.a. & 570,442 & 7,534 & 1.32 & 0.17 \\
Low & n.a. & $1,316,872$ & 17,288 & 1.31 & 0.39 \\
Total & n.a. & $\mathbf{4 , 4 0 7 , 0 7 7}$ & $\mathbf{1 8 7 , 8 1 1}$ & $\mathbf{4 . 2 6}$ & $\mathbf{4 . 2 6}$ \\
\hline
\end{tabular}

Source: Business R\&D and Innovation Survey (BRDIS).Elaborated by the author. Note: n.a. - not available.

TABLE 5

Expenditures in internal and external R\&D activities and net sales according to technological intensity, manufacturing industry

Canada - 2006

\begin{tabular}{l|c|c|c|c|c}
\hline $\begin{array}{l}\text { Technological } \\
\text { intensity }\end{array}$ & $\begin{array}{c}\text { Number of } \\
\text { firms }\end{array}$ & $\begin{array}{c}\text { Net sales } \\
\mathbf{( U \$ \$ \$} \\
\text { thousands) }\end{array}$ & $\begin{array}{c}\text { Spending on } \\
\text { internal and } \\
\text { external R\&D } \\
\text { activities (U\$\$ } \\
\text { thousands) }\end{array}$ & $\begin{array}{c}\text { Spending on } \\
\text { internal and } \\
\text { external R\&D } \\
\text { activities / net } \\
\text { sales (\%) }\end{array}$ & $\begin{array}{c}\text { Contribution to } \\
\text { the average of the } \\
\text { manufacturing } \\
\text { industry } \\
\text { (equation 4) (\%) }\end{array}$ \\
\hline High & n.a. & $32,146,000$ & $3,084,692$ & 9.60 & 0.47 \\
Medium-high & n.a. & $209,486,000$ & $2,505,660$ & 1.20 & 0.38 \\
Medium-low & n.a. & $198,960,000$ & 379,475 & 0.19 & 0.06 \\
Low & n.a. & $219,204,000$ & $1,007,802$ & 0.46 & 0.15 \\
Total & n.a. & $\mathbf{6 5 9 , 7 9 6 , 0 0 0}$ & $\mathbf{6 , 9 7 7 , 6 2 9}$ & $\mathbf{1 . 0 6}$ & $\mathbf{1 . 0 6}$ \\
\hline
\end{tabular}

Source: OECD. Elaborated by the author.

Note: n.a. - not available. 
Although the magnitude of the ratios R\&D / net sales are not directly comparable with the indicators obtained for Brazil or Germany, a brief analysis of the data reveals that, in the United States, high and medium-high technology (with represent $57 \%$ of the total net sales) contribute with more than $85 \%$ of the national average. In Canada, where these two groups represent only 36\% of the industrial structure (i.e., of the total net sales), the contribution of high and medium-high sectors to the national average R\&D intensity is $0.85 \%$ in $1.06 \%$ (i.e., above $80 \%$ ).

The data about Germany, the United States and Canada are useful to look on the ways to increase business enterprise R\&D in Brazil. The rule of thumb of all these analysis is that in R\&D intensive countries the share of high and medium-high sectors is usually between 40\% and 60\% (Graph 1). However, as shown in Graph 1 , this condition seems to be necessary, but not sufficient to reach higher levels of business enterprise R\&D expenditures. In fact, in Graph 1, some countries of the lower "cloud" present shares of high and medium-high sectors above $40 \%$ but ratios R\&D / net sales below 1.00\%. However, no country of the upper "cloud" reaches higher levels of ratios R\&D / net sales without a relevant high and medium-high technology sector. In a country like the United States, where the average ratio R\&D I net sales is above $4 \%$ and there is a significant presence of medium-low and low technology sector in its industrial structure - as a consequence of the countries' natural factors endowment -, the share of high and medium-high technology sectors in the industrial structure is almost 60\%. In Canada, the share of these sectors in the industrial structure is only 36\%; accordingly, the ratio R\&D / net sales is $1.06 \%$.

As mentioned in the introduction of this paper, one of the targets of the Brazilian industrial policy issued in 2011 is to reach a ratio between business enterprise R\&D expenditures and GDP of $0.90 \%$ in 2014. Assuming a linear relationship between the ratios business enterprise R\&D expenditures / GDP and the R\&D / net sales for the manufacturing industry, Brazil should raise the latter from $0.75 \%$ in 2008 to $1.06 \%$ in $2014 .{ }^{16}$ This is exactly the Canadian average ratio R\&D / net sales, which makes this country an interesting benchmark for the Brazilian case. Besides, the shares of high and medium-high technology sectors in Brazil and in Canada are pretty similar (38.25\% and 36.62\%). However, while in Brazil the high technology sector invests $1.89 \%$ of its net sales in $\mathrm{R} \& \mathrm{D}$, in Canada this ratio reaches $9.60 \%$. As a result, the contribution of the high technology sector to the national average in Canada $(0.47 \%)$ is much higher than in Brazil $(0.10 \%)$. The 
contributions of the remaining groups (medium-high, and medium-low and low technology considered as a single group) are similar in the two countries $(0.37 \%$ and $0.27 \%$ in Brazil, and $0.38 \%$ and $0.21 \%$ in Canada). In other words: if Canada is a benchmark for Brazil, there is not much room left for improvements in the ratio $R \& D$ / net sales in lower technologies.

When the arguments of the previous paragraph are placed together with the fact that high and medium-high technology sectors represent a much smaller share of the number of firms in Brazil, it becomes hard to deny that if the target is to increase the ratio between business enterprise R\&D expenditures and GDP, the focus should be placed on high and medium-high sectors. This apparently straightforward conclusion reinforces the perception stated after the analyses of Tables 1 and 2: the increasing of Brazilian average R\&D expenditures seems to be much easier if the focus is placed on high and medium-high technology firms. Instead of contradicting the numerous analyses which place the focus of innovation policies on small and medium firms and on the catching up of traditional sectors in developing countries, this conclusion seems to indicate the limitations of the R\&D expenditures / GPD indicator as a single target for this kind of policy. In fact, there seems to be room for the catching up of medium-low and low technology sectors in Brazil through incremental innovations and technical issues not directly associated to $R \& D$ expenditures.

\section{Concluding remarks}

In this paper, the business enterprise $R \& D$ expenditures were decomposed to stress the role of the individual firms' innovation efforts and of the industrial structure in the determination of the aggregate levels of this indicator in Brazil. Using data from the Brazilian Innovation Survey, from the Community Innovation Survey (CIS) and from the Organization for Economic Co-operation and Development (OECD) and based on the aggregation of the sectors that comprise the manufacturing industry into four groups according to their technological intensity (high, medium-high, medium-low and low technology), the ratio between R\&D expenditures and net sales in Brazil was analyzed and compared with the ratios observed in Germany, in the United States and in Canada.

It was shown that, due to a set of methodological limitations of the output indicators, input indicators such as the ratio between business enterprise R\&D expenditures and the GDP are frequently used as a target for innovation policies 
in several countries. In fact, input indicators remain in the center of all debates about public ST\&I policies both in the OECD countries and in countries such as Brazil. As these indicators result from firms' or sectors' R\&D intensity weighted by their relative share in the industrial structure, the decomposition used in this paper indicated ways to increase business enterprise $R \& D$ expenditures in Brazil. It was shown that i) high and medium-high technology sectors, which represent less than $15 \%$ of the total sample of firms used in the Brazilian innovation survey, contribute with $0.47 \%$ to the formation of the national average of $0.75 \%$; ii) gaps for high and medium-high technological intensity firms in Brazil are especially noteworthy when compared to the countries used as reference in this paper; iii) on the other hand, the gap between medium-low and low technology sectors in Brazil and in the reference countries are not expressive, indicating that there is not much room left for improvements in the ratio R\&D expenditures / net sales in these sectors. Besides, hypothetical scenarios for the Brazilian ratio R\&D expenditures / net sales were built upon the data regarding Germany. Although these scenarios may suggest a higher impact of groups' R\&D intensities as compared to industrial structure, it was shown that ratio $\mathrm{R} \& \mathrm{D}$ expenditures / net sales is, by its own definition, less sensitive to $w_{i}$ than to $t i_{i}$. These scenarios reinforce the perception that the increasing of high and medium-high technology sectors' both share in the local industrial structure and $R \& D$ intensity may allow a more rapid upgrade in the national ratio business enterprise R\&D expenditures / GDP.

The main conclusions of this paper suggest that, if the target of Brazilian innovation policy is to increase the ratio business enterprise $R \& D$ expenditures / GDP to $0.90 \%$ in 2014 , the focus should be placed on high and medium-high technology sectors, both increasing their share in the local industrial structure (thought industrial policies, for example) and increasing their R\&D intensity. This apparently straightforward conclusion reinforces the perception that the increasing of Brazilian average R\&D expenditures seems to be much easier if the focus is placed on high and medium-high technology firms. Instead of contradicting the numerous analyses which place the focus of innovation policies on small and medium firms and on the catching up of traditional sectors in developing countries, this conclusion seems to indicate the limitations of the R\&D expenditures / GPD indicator as a single target for this kind of policy. In fact, there seems to be room for the catching up of medium-low and low technology sectors in Brazil through incremental innovations and technical issues not directly associated to R\&D expenditures. As a result, additional instruments targeting medium-low and low technology sectors should 
be used in order to allow them to benefit from incremental innovations and from the absorption of practices not directly related to R\&D.

\section{References}

ARAÚJO, B. C. et al. Impacts of the Brazilian science and technology sectoral funds on the industrial firms' R\&D inputs and outputs. In: Fourth Conference on Micro Evidence on Innovation in Developing Economies. Tartu, Estonia, 2010. Available at $<$ http://www. merit.unu.edu/MEIDE/papers/2010/Araujo_et_al.pdf>. Access on: Jul. 21st 2010.

ARAÚJO, B. C.; CAVALCANTE, L. R. Determinantes dos gastos empresariais em pesquisa e desenvolvimento no Brasil: uma proposta de sistematização. Radar - Tecnologia, Produção e Comércio Exterior, n. 16, p. 9-18, 2011.

ARRUDA, M.; VELMULM, R.; HOLLANDA, S. Inovação tecnológica no Brasil: a indústria em busca da competitividade global. São Paulo: Associação Nacional de Pesquisa, Desenvolvimento e Engenharia das Empresas Inovadoras (Anpei), 2006.

ARUNDEL, A. Innovation survey indicators: any progress since 1996? In: BLUE SKY II INDICATORS CONFERENCE. Ottawa, 2006. Available at: <em http://www.oecd.org/ dataoecd/24/28/37436234.pdf>. Access on: May 172011.

. Innovation survey indicators: what impact on innovation policies? In: OECD - Organization for Economic Co-operation and Development. Science, technology and innovation indicators in a changing world: responding to policy needs. Paris: OECD, 2007.

AVELLAR, A. P. Avaliação do impacto do PDTI sobre o gasto em atividades de inovação em P\&D das empresas industriais. In: DE NEGRI, J. A.; KUBOTA, L. C. (Orgs.). Politicas de incentivo à inovação tecnológica no Brasil. Brasília: Ipea, 2008.

CASSIOLATO, J. E.; LASTRES, H. M. (Orgs.). Globalização e inovação localizada: experiências de sistemas locais no Mercosul. Brasília: IBICT/MCT, 1999.

CAVALCANTE, L. R.; DE NEGRI, F. PINTEC 2008: análise preliminar e agenda de pesquisa. Radar - Tecnologia, Produção e Comércio Exterior, n. 12, p. 7-16, 2010.

. Trajetória recente dos indicadores de inovação no Brasil. Rio de Janeiro: Ipea, set. 2011 (Texto para discussão, n. 1659).

CRESPI, G.; NAVARRO, J. C.; ZUNIGA, P. Políticas de ciencia, tecnología e innovación en América Latina: dónde estamos y que hemos aprendido. Washington, Feb. 2011 (mimeo).

DE NEGRI, J. A.; DE NEGRI, F.; LEMOS. M. B. O impacto do FNDCT sobre o desempenho e o esforço tecnológico das empresas industriais brasileiras. In: DE NEGRI, J. 
A.; KUBOTA, L. C. (Orgs.). Políticas de incentivo à inovação tecnológica no Brasil. Brasília: Ipea, 2008a.

O impacto do programa ADTEN sobre o desempenho e o esforço tecnológico das empresas industriais brasileiras. In: DE NEGRI, J. A.; KUBOTA, L. C. (Orgs.). Políticas de incentivo à inovação tecnológica no Brasil. Brasília: Ipea, 2008b.

EUROPEAN COMISSION. Innovation Union Competitiveness report 2011. Analysis Part I: Investment and performance in R\&D - Investing in the future. European Union, 2011. Available at: <http://ec.europa.eu/research/innovation-union/pdf/competitiveness-report/2011/ part_1.pdf>. Access on: Jun. 16 2012.

FREEMAN. C.; SOETE, L. Developing science, technology and innovation indicators: what we can learn from the past. United Nations University/Maastricht Economic and Social Research and Training Centre on Innovation and Technology, UNU/MERIT, 2007 (Working paper series 2007-001).

FURTADO, A. T.; CARVAlHO, R. Q. Padrōes de intensidade tecnológica da indústria brasileira: um estudo comparativo com os países centrais. São Paulo em Perspectiva, v. 19, n. 1, p. 70-84, 2005.

GODIN. B. The rise of innovation surveys: measuring a fuzzy concept. Project on the history and sociology of STI statistics, n.d. (Working paper, n. 16).

IBGE - Instituto Brasileiro de Geografia e Estatística/Coordenação de Indústria. Pesquisa de Inovação Tecnológica 2005. Rio de Janeiro: IBGE, 2007.

Pesquisa de Inovação Tecnológica 2008. Rio de Janeiro: IBGE, 2010.

MALONEY, W.; RODRÍGUEZ-CLARE, A. Innovation shortfalls. Review of Development Economics, v. 11, n. 4, p. 665-684, 2007.

MORAIS, J. M. Uma avaliação dos programas de apoio financeiro à inovação tecnológica com base nos fundos setoriais e na lei de inovação. In: DE NEGRI, J. A.; KUBOTA, L. C. (Orgs.). Políticas de incentivo à inovação tecnológica no Brasil. Brasília: Ipea, 2008.

OECD - Organization for Economic Co-operation and Development. Guideliness for collecting and interpreting innovation data. 3rd ed. Paris: OECD, 2005.

PAVITT, K. Sectoral patterns of technical change: towards a taxonomy and a theory. Research Policy, v. 13, p. 343-373, 1984.

ZUCOLOTO, G. F; TONETO JR., R. Esforço tecnológico da indústria de transformação brasileira: uma comparação com países selecionados. Revista de Economia Contemporânea, v. 9, n. 2, maio-ago. 2005. 
